\title{
Assessing the potential value of bridge monitoring systems
}

Paul J. Vardanega BE, MEngSc QIdUT, PhD Cantab, MASCE, MIEAust Lecturer in Civil Engineering, Department of Civil Engineering, University of Bristol, Bristol, UK (corresponding author: p.j.vardanega@bristol.ac.uk)

Graham T. Webb MEng, MA, PhD Cantab

Engineer, WSPI Parsons Brinkerhoff, London, UK; Formerly, Doctoral Student, Department of Engineering, University of Cambridge,

Cambridge, UK
Paul R. A. Fidler MA Cantab

Computer Associate, Department of Engineering, University of Cambridge,

Cambridge, UK

Campbell R. Middleton BE(Hons) Tas, MSc DIC Lond, PhD Cantab, FICE, MIEAust, CEng, CPEng

Laing O'Rourke Professor of Construction Engineering, Department of

Engineering, University of Cambridge, Cambridge, UK

On-going developments in smart technologies such as wireless sensor networks, micro-electro-mechanical systems (MEMS), computer vision, fibre optics and advanced data interpretation techniques may revolutionise structural health monitoring (SHM). Dedicated SHM of bridge assets has the potential to produce valuable data-sets and provide owners and managers with information to aid with key questions such as: current performance, margins of safety, actual loading, stress history and risk of fatigue, extent of deterioration and residual life. However, the parameters measured and value of the data obtained will differ when viewed from the perspectives of different stakeholders such as asset owners, designers, contractors and researchers. In this paper the purposes of monitoring are reviewed. A methodology is proposed to facilitate formal discussions between the key stakeholders before any deployment is specified and to ensure that scarce resources are not wasted in the pursuit of data as opposed to information. This approach can be used to determine if there is a prima facie case for the specification of SHM on a project and assess the potential value of any information that may be obtained. The developed methodology has been trialled with five historical monitoring case studies on bridges with which the authors are familiar.

\section{Introduction}

Structural health monitoring (SHM) is becoming a standard feature of many major bridge projects (e.g., Catbas et al., 2013; $\mathrm{Ko}$ and $\mathrm{Ni}, 2005)$. High-profile bridges such as Stonecutters Bridge in Hong Kong have had extensive monitoring systems installed (Wong, 2004). Many bridges in the UK have or have had SHM systems installed; for example, Humber Bridge (Hoult et al., 2008); Nine Wells Bridge (Hoult et al., 2009; Schwamb, 2010; Webb, 2014); Ferriby Road Bridge (Hoult et al., 2010); Hammersmith flyover (Webb et al., 2014).

There have been numerous publications discussing how to deploy SHM systems and obtain data (e.g., Andersen and Vesterinen, 2006; BTS, 2011; Catbas et al., 2013; Feltrin, 2007; Gastineau et al., 2009; Koo et al., 2013; Kurata et al., 2013). However, the collection of data (in the bridge engineering context) is of little value in-and-of itself unless it can be used to inform and influence decision making. When discussing benefits to stakeholders, an early paper describing the role of sensor technologies for civil infrastructure management by Maser (1988) is worth revisiting. Maser (1988) wrote:

In spite of the current climate of technological abundance, these developments are significantly inhibited by the absence of a clear connection between the sensor system capabilities and the needs of the infrastructure management organization.

Maser's observation reveals that simply being able to measure a parameter does not mean that a specific need or piece of critical information is being obtained.

Five categories developed by Webb et al. (2015) are shown in Table 1 and describe different ways in which monitoring data can be used to provide different types of information. Table 1 also gives a description of what each type of deployment seeks to achieve. As was noted by Webb et al. (2015), many SHM deployments have aspects that can fit into more than one of the categories, namely: sensor deployment studies, anomaly detection, model validation, threshold check and damage detection.

\section{Value assessment methodology for bridge structural health monitoring}

\subsection{Developing the case for monitoring}

In many monitoring situations there are a number of different stakeholder groups who may be able to benefit. In the work of Andersen and Vesterinen (2006) on the design and planning of 
1 Sensor deployment studies

2 Anomaly detection

3 Model validation

4 Threshold check

5 Damage detection
Demonstration of the ability of a sensor to measure a parameter of interest and of a communication system to transmit the data to the operators.

Detection of change in a parameter with time, for example many systems strive to detect natural frequency of vibration and notice changes that may represent a change in stiffness. However, changes can be due to many causes, such as condition, temperature, humidity and live loading.

A system that aims to compare measured values with predictions from a structural model to quantify whether or not the structure is behaving as expected. The caveat is that structural responses are relative easy to detect, whereas input loads are difficult to quantify.

Comparison of measurements with a threshold level, derived at least in part, from a model of structural behaviour, beyond which action should be taken.

Detailed investigation to detect the type, location, extent and rate of damage or deterioration at one or more locations.

Table 1. Categories of SHM systems

SHM systems seven stakeholders were identified, namely: (a) authorities, $(b)$ owners, $(c)$ users, $(d)$ researchers, $(e)$ designers, $(f)$ contractors and $(g)$ operators. It is acknowledged that all seven stakeholders can benefit from SHM on bridges, but in different ways. Figure 1 has been proposed by the present authors to visually indicate the series of considerations that should be examined when deciding whether or not there is a prima facie case for SHM. It is important to note that the choice of technology itself, for example, fibre optic strain gauges or micro-electro-mechanical systems (MEMS) sensors, is a much later consideration compared with the more highlevel considerations of 'why', 'where', 'what' and 'for whom' for example. If a prima facie case does exist, the next stage is to assess whether or not the proposed monitoring deployment could generate value to at least one stakeholder.

\subsection{Developing a value assessment methodology}

Having decided whether or not there is a prima facie requirement for an SHM system, the next stage is to determine if an installed system will in fact yield value. In principle, some value from any of the measurements will be delivered to some stakeholders; however, the proposed value assessment system is targeted pragmatically at owners and managers - who arguably are interested in a more immediate return on investment than, for example, researchers.

Yanev (2007) and Cole (2008) present more general reviews of bridge management and bridge assessment philosophy, respectively. A value assessment methodology for bridge engineers to decide if a proposed SHM deployment will deliver value to bridge owners is now presented. It is partly inspired by a recently published methodology for assessing the value of remote sensing technologies proposed by Vaghefi et al. (2012)

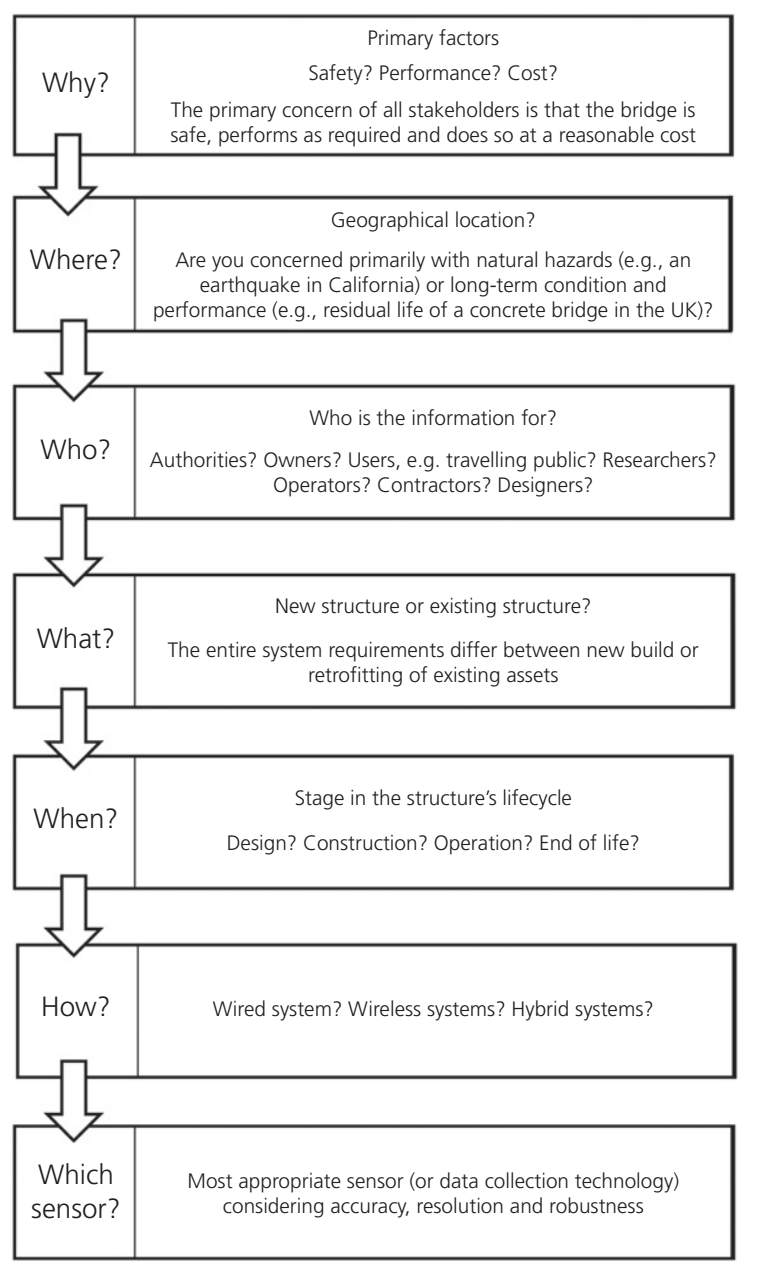

Figure 1. Main considerations when examining whether or not to employ a structural health monitoring system 


\begin{tabular}{|c|c|c|c|c|c|c|c|}
\hline & & 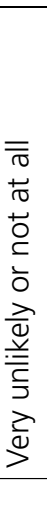 & 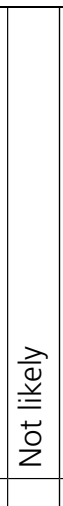 & 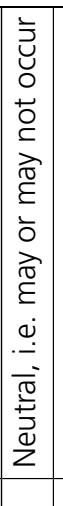 & 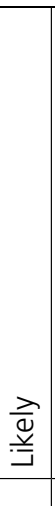 & 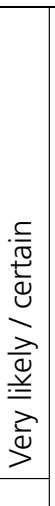 & \\
\hline & Question & 1 & 2 & 3 & 4 & 5 & Comments \\
\hline \multirow[t]{3}{*}{ SHM engineer } & How likely is it that the required accuracy of the proposed measurements can be ascertained? & & & & & & \\
\hline & $\begin{array}{l}\text { How likely is it that the specified system can be designed to be sufficiently robust such that it } \\
\text { can be maintained over the life of the monitoring project? }\end{array}$ & & & & & & \\
\hline & $\begin{array}{l}\text { How likely is it that the appropriate auditing will be conducted by a third party to certify that } \\
\text { the gathered data are reliable? } \\
\text { (For example, monthly reports that give details of calibrations undertaken and 'sanity } \\
\text { checking' of collected data.) }\end{array}$ & & & & & & \\
\hline \multirow[t]{3}{*}{$\begin{array}{l}\text { Structural } \\
\text { engineer }\end{array}$} & $\begin{array}{l}\text { How likely is it that relevant values of appropriate threshold values will be assigned in } \\
\text { consultation with the asset owner so as to ensure that the owner will act if these values are } \\
\text { realised in the field? }\end{array}$ & & & & & & \\
\hline & How likely is it that the critical monitoring locations on the structure can be determined? & & & & & & \\
\hline & $\begin{array}{l}\text { How likely is it that the data be used for validation (or falsification) of structural models which } \\
\text { may assist with the design of more efficient future structures for the asset owner? }\end{array}$ & & & & & & \\
\hline \multirow[t]{3}{*}{$\begin{array}{l}\text { Owner/Asset } \\
\text { manager }\end{array}$} & $\begin{array}{l}\text { How likely is it that the necessary actions (or decisions) will be taken if threshold (trigger) } \\
\text { values are exceeded/reached? }\end{array}$ & & & & & & \\
\hline & How likely is it that the data to be collected will be able to inform a maintenance regime? & & & & & & \\
\hline & $\begin{array}{l}\text { How likely is it that there will be a secure budget necessary for the intended period of } \\
\text { operation of the monitoring project? }\end{array}$ & & & & & & \\
\hline & Average & & & & & & \\
\hline
\end{tabular}

Table 2. Pre-monitoring value assessment matrix (to be filled in

during a meeting involving the SHM engineer, structural engineer

and asset owner or manager) 
0.0 to 1.0

1.0 to 2.0

2.0 to 3.0

3.0 to 4.0

4.0 to 5.0
Project very unlikely to yield value to the asset owner/manager Project unlikely to yield value to the asset owner/manager Project may yield value to the asset owner/manager Project likely to yield value to the asset owner/manager Project very likely to yield value to the asset owner/manager

Table 3. VR-index ranges

and the procedure for the assignment of geotechnical reduction factors outlined in Poulos (2004).

To provide value for the bridge owner input is needed from three key players: SHM engineers, structural engineers and the bridge's owners.

- SHM engineers aim to provide instrumentation systems to produce measurement data from a structure, and quantify the expected level of accuracy and error rates.

- Structural engineers aim to provide appropriate structural models and data interpretation techniques along with meaningful 'trigger values' that have a sound technical basis. SHM engineers should then be confident of what they need to measure, why they need to measure it and the accuracy (or resolution) required to provide the information needed by the structural engineer. It should also be noted that structural engineers may be employed by contractors to assist with the assignment of critical values that are relevant to quality and speed of construction.

- Owners/asset managers aim to fix issues identified by the SHM system if empowered to act once informed that a trigger value or limit has been reached. They want maximum performance at minimum cost.

All three key players need to contribute to delivering value and the next section proposes a methodology that they can use in partnership. As previously stated, the focus here is on delivery of value to an asset owner and the methodology would need revision if the focus was on delivery of value to another stakeholder.

\subsection{Use of the value rating matrix}

The user of the methodology assigns a value rating (VR) from 1 to 5 to the various criteria listed in Table 2. The most important phase of filling out Table 2 is arguably the writing of the comments justifying the score allocated. The VR-index is computed by simply averaging the scores given to the nine questions listed in Table 2. The computed VR-index is a simple metric that can be used to quantitatively compare different monitoring strategies and decide whether a particular SHM configuration may be worthwhile for a particular project (see Table 3).

\section{Case studies}

To demonstrate the use of the value rating system that has been proposed, five bridge projects with which the authors are familiar have been used to provide hypothetical value rating scores of actual or proposed monitoring systems. All five case studies are also described in more detail in Webb (2014).

\subsection{Walton Bridge (Middleton et al., 2014 and Webb, 2014)}

Walton Bridge is a newly constructed road bridge across the river Thames between Walton-on-Thames and Shepperton in London (further details are provided in Middleton et al., 2014; Webb, 2014). Completed in 2013, it is the sixth bridge to have occupied this site, constructed to replace two existing bridges. The new bridge consists of a steel arch spanning approximately $90 \mathrm{~m}$ and approach viaducts. There were originally no plans to install a monitoring system on the new Walton Bridge. This provided an opportunity to consider carefully whether SHM could add value to the project, as there were no preconceived ideas about what should be installed. Questions as to what could be measured to provide value for the client were asked. Deterioration of a number of critical components was considered. In this paper, the bridge's arch is considered in more detail.

The bridge's arch is constructed from steel and so, as with all steel structures, corrosion is a concern. Unfortunately, corrosion cannot yet be easily and reliably detected at all locations on a structure. One option is to measure relative humidity levels and if these are kept below $60 \%$ then corrosion of exposed steel is considered unlikely to occur (cf. Bloomstine, 2011). It was therefore suggested that relative humidity sensors could be installed within the steel arch and a threshold check could be used to alert the bridge's owners should the relative humidity increase to unacceptable levels. However, the arch had been designed with a protective coating expected to last 60 years and also with additional sacrificial thickness to allow corrosion to occur for an additional 60 years before causing problems. Since the risks due to corrosion have effectively been 'designed out' a relative humidity monitoring system would not affect the management of the bridge. Running such a system was not deemed to offer any clear benefits. 


\begin{tabular}{|c|c|c|c|c|c|c|c|}
\hline & & 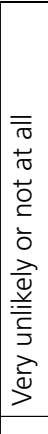 & 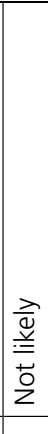 & 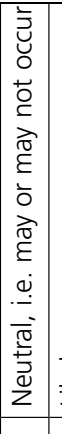 & 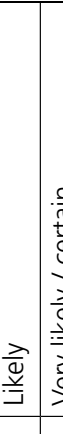 & 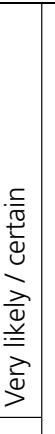 & \\
\hline & Question & 1 & 2 & 3 & 4 & 5 & Comments \\
\hline \multirow[t]{3}{*}{ SHM engineer } & $\begin{array}{l}\text { How likely is it that the required accuracy of the proposed measurements can be } \\
\text { ascertained? }\end{array}$ & $\mathrm{x}$ & & & & & $\begin{array}{l}\text { Prediction of failure is difficult (if not } \\
\text { impossible). }\end{array}$ \\
\hline & $\begin{array}{l}\text { How likely is it that the specified system can be designed to be sufficiently robust such that it } \\
\text { can be maintained over the life of the monitoring project? }\end{array}$ & & & & $x$ & & $\begin{array}{l}\text { Monitoring systems' standards of robustness } \\
\text { are arguably improving. }\end{array}$ \\
\hline & $\begin{array}{l}\text { How likely is it that the appropriate auditing will be conducted by a third party to certify that } \\
\text { the gathered data are reliable? } \\
\text { (For example, monthly reports that give details of calibrations undertaken and 'sanity } \\
\text { checking' of collected data.) }\end{array}$ & $x$ & & & & & \\
\hline \multirow[t]{3}{*}{$\begin{array}{l}\text { Structural } \\
\text { engineer }\end{array}$} & $\begin{array}{l}\text { How likely is it that relevant values of appropriate threshold values will be assigned in } \\
\text { consultation with the asset owner so as to ensure that the owner will act if these values } \\
\text { are realised in the field? }\end{array}$ & $\mathrm{x}$ & & & & & $\begin{array}{l}\text { A meeting was held with representatives of the } \\
\text { owner, designer, contractor and researchers } \\
\text { present. No suitable quantities to measure } \\
\text { were found that would be useful to either } \\
\text { the owner or designers. }\end{array}$ \\
\hline & How likely is it that the critical monitoring locations on the structure can be determined? & $\mathrm{x}$ & & & & & Was not possible during the discussions. \\
\hline & $\begin{array}{l}\text { How likely is it that the data be used for validation (or falsification) of structural models } \\
\text { which may assist with the design of more efficient future structures for the asset owner? }\end{array}$ & & & $\mathrm{x}$ & & & $\begin{array}{l}\text { In hindsight may have been a deliverable from } \\
\text { the project. }\end{array}$ \\
\hline \multirow[t]{3}{*}{$\begin{array}{l}\text { Owner/Asset } \\
\text { manager }\end{array}$} & $\begin{array}{l}\text { How likely is it that the necessary actions (or decisions) will be taken if threshold (trigger) } \\
\text { values are exceeded/reached? }\end{array}$ & $\mathrm{x}$ & & & & & No sensible trigger values could be determined. \\
\hline & How likely is it that the data to be collected will be able to inform a maintenance regime? & $x$ & & & & & No sensible measurand(s) could be determined. \\
\hline & $\begin{array}{l}\text { How likely is it that there will be a secure budget necessary for the intended period of } \\
\text { operation of the monitoring project? }\end{array}$ & & & & $\mathrm{x}$ & & $\begin{array}{l}\text { Willing client so budget probably would have } \\
\text { been secure. }\end{array}$ \\
\hline & Average & \multicolumn{5}{|c|}{$1 \cdot 9$} & $\begin{array}{l}\text { Project unlikely to yield value to the asset } \\
\text { owner/manager. }\end{array}$ \\
\hline
\end{tabular}

Table 4. Simulated pre-monitoring value assessment matrix

(Walton Bridge) 


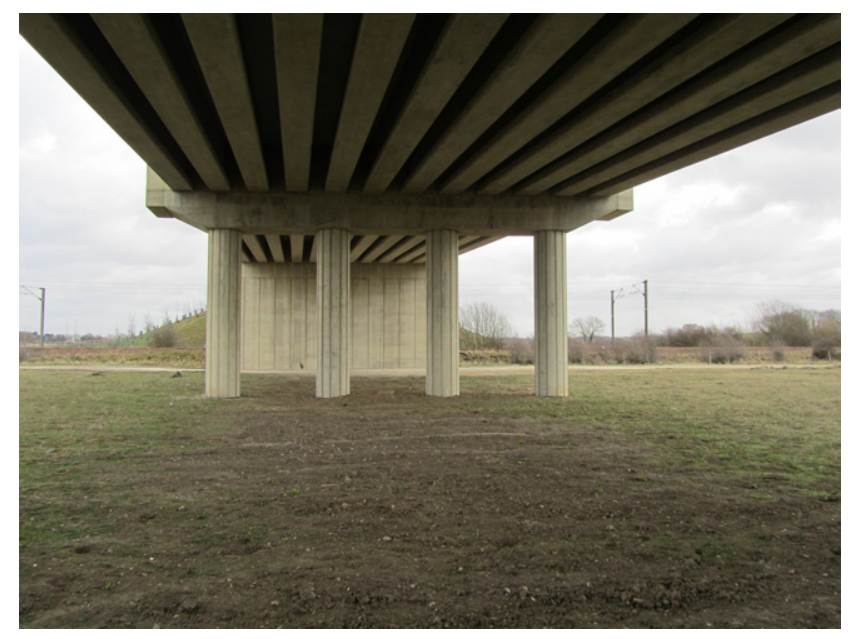

Figure 2. Nine Wells Bridge, Cambridgeshire (Photograph: Authors)

Another option considered was the use of fibre optic cables that could be installed within the arch to measure strains throughout its length. These could be used to gain a better understanding of how loads are transmitted through the bridge's arch and validate the design assumptions/predictions. However this would be of very little value to the bridge's owners, especially without a full knowledge of the input loading. Such data may prove interesting to researchers or code writers, but this would not justify the required expense to the bridge's owners.

Eventually no monitoring system was installed; however, perhaps with the benefit of hindsight, a model validation study (see Table 1) could have been useful to engineers and researchers to inform/influence future steel arch bridge designs. Table 4 shows the pre-monitoring assessment matrix filled out (albeit hypothetically) with a resulting VR-index of 1.9. Based on the rating from Table 3 the project 'is unlikely to yield value to the asset owner/manager'. Given the results of the discussions this score seems reasonable.

\subsection{Nine Wells Bridge (Hoult et al., 2009, Schwamb, 2010; Webb, 2014)}

The Nine Wells Bridge (Figure 2) was constructed to the south west of Addenbrooke's Hospital in Cambridgeshire in 2008 (further details are provided in Hoult et al., 2009, Schwamb, 2010; Webb, 2014). The bridge comprises three spans, each of approximately $30 \mathrm{~m}$ in length, and is constructed from precast, pre-stressed concrete 'Y beams' with an in situ concrete deck. Both the intermediate piers and the abutments are supported on piled raft foundations. The instrumentation installed on this bridge consisted of a number of fibre optic cables, which can be interrogated using a technique called Brillouin optical time domain reflectometry (BOTDR) to measure strains (e.g.,
Kurashima et al., 1993). This would be classified as a 'category 1: sensor deployment study' according to Table 1. Six of the beams in the most western span of the Nine Wells Bridge were constructed with optical fibres cast into the concrete, allowing distributed strain measurements to be taken along the lengths of each beam. Some of the details of the installation are discussed by Hoult et al. (2009) and Schwamb (2010). Unfortunately, damage during installation to some of the fibre optic cables used in this experimental deployment limited the data that could be acquired, while subsequent vandalism to the cables had rendered the system inoperable after about two years. However, the main benefit derived was from learning how to interpret the data from the new sensor systems (cf. Webb, 2014), although this took some years to realise and the real beneficiaries of this are design engineers who may be involved in future endeavours rather than to the owners/operators of this bridge. Table 5 shows the pre-monitoring assessment matrix filled out (albeit hypothetically, but after an actual project was completed) with a VR-index of $2 \cdot 1$ resulting. Based on the rating from Table 3, the project 'may yield value to the asset owner/manager'. This slightly better result than for Walton Bridge is because some useful research data could become available for model validation, and hence the scores for the three 'structural engineer questions' were higher.

\subsection{Humber Bridge - Hessle Anchorage (Hoult et al., 2008)}

The Humber Bridge near Hull was completed in 1981 and is the UK's longest suspension bridge (Hoult et al., 2008). A dehumidification system had been installed in each anchorage chamber (where the main cables of the suspension bridge are not coated with a protective sheath, see Figure 3 ) to ensure that corrosion is inhibited by keeping the relative humidity below a threshold level of $60 \%$ (cf. Bloomstine, 2011). Relative humidity sensors were installed in the chambers to control the dehumidification system. Humidity levels reported by these sensors could also be viewed on liquid-crystal display (LCD) panels from within the anchorage chambers. In July 2007, a wireless monitoring system consisting of a number of temperature and relative humidity sensors was installed in the northern anchorage chamber to supplement the existing wired system (Hoult et al., 2008). Sensors were placed adjacent to the existing sensors, as well as in other locations such as suspended directly adjacent to the steel cables. This system provided the bridge manager with hourly data by way of a website, with the potential for alerting the user to any failures of the dehumidification system in near real time. Additionally it was discovered that the dehumidifiers in the two sides of the northern anchorage chamber had been configured very differently in terms of their switching threshold levels and that significant energy and cost savings could be made by optimising their operation. Although primarily conceived as a threshold check, this example also demonstrates an anomaly detection study providing a serendipitous benefit. This 


\begin{tabular}{|c|c|c|c|c|c|c|c|}
\hline & & 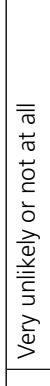 & 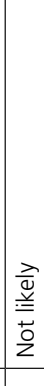 & 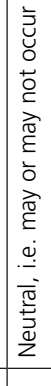 & 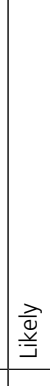 & 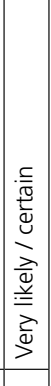 & \\
\hline & Question & 1 & 2 & 3 & 4 & 5 & Comments \\
\hline \multirow[t]{3}{*}{$\begin{array}{l}\text { SHM } \\
\text { engineer }\end{array}$} & $\begin{array}{l}\text { How likely is it that the required accuracy of the proposed measurements can be } \\
\text { ascertained? }\end{array}$ & & $x$ & & & & $\begin{array}{l}\text { Fibre optic (FO) technology was installed as part of a research project. Accuracy and } \\
\text { precision of FO for monitoring is still the subject of research. }\end{array}$ \\
\hline & $\begin{array}{l}\text { How likely is it that the specified system can be designed to be sufficiently robust } \\
\text { such that it can be maintained over the life of the monitoring project? }\end{array}$ & $x$ & & & & & $\begin{array}{l}\text { The FO cables selected for the research project were not very robust. They were } \\
\text { inexpensive telecommunications fibres and one aim of the research was to study } \\
\text { how they would perform in a harsh construction environment. Many fibres were } \\
\text { damaged during casting, transportation and installation of the concrete beams. } \\
\text { Once installed the fibres were prone to further damage from vandalism. }\end{array}$ \\
\hline & $\begin{array}{l}\text { How likely is it that the appropriate auditing will be conducted by a third party to } \\
\text { certify that the gathered data are reliable? } \\
\text { (For example, monthly reports that give details of calibrations undertaken and } \\
\text { 'sanity checking' of collected data.) }\end{array}$ & $x$ & & & & & $\begin{array}{l}\text { While some data were gathered, due to the fact that little is known about what is } \\
\text { 'quality' FO data, no auditing was carried out. }\end{array}$ \\
\hline \multirow[t]{3}{*}{$\begin{array}{l}\text { Structural } \\
\text { engineer }\end{array}$} & $\begin{array}{l}\text { How likely is it that relevant values of appropriate threshold values will be assigned } \\
\text { in consultation with the asset owner so as to ensure that the owner will act if } \\
\text { these values are realised in the field? }\end{array}$ & & $x$ & & & & $\begin{array}{l}\text { Appropriate threshold values were not determined, but some estimates } \\
\text { (calculations) of expected creep and shrinkage values were made. The primary } \\
\text { purpose of the deployment was to validate strain readings from the FO system } \\
\text { (see Hoult et al., 2009). }\end{array}$ \\
\hline & $\begin{array}{l}\text { How likely is it that the critical monitoring locations on the structure can be } \\
\text { determined? }\end{array}$ & & & & $x$ & & $\begin{array}{l}\text { Installation of the fibres cast in situ was done and this meant that some data for } \\
\text { validation of creep and shrinkage models were available. }\end{array}$ \\
\hline & $\begin{array}{l}\text { How likely is it that the data be used for validation (or falsification) of structural } \\
\text { models which may assist with the design of more efficient future structures for } \\
\text { the asset owner? }\end{array}$ & & & $x$ & & & $\begin{array}{l}\text { Primary use was to validate the use of FO technology but some of the data could } \\
\text { be used to validate or at least compare with creep and shrinkage models. }\end{array}$ \\
\hline \multirow[t]{3}{*}{$\begin{array}{l}\text { Owner/Asset } \\
\text { manager }\end{array}$} & $\begin{array}{l}\text { How likely is it that the necessary actions (or decisions) will be taken if threshold } \\
\text { (trigger) values are exceeded/reached? }\end{array}$ & $x$ & & & & & No threshold or trigger values were set. \\
\hline & $\begin{array}{l}\text { How likely is it that the data to be collected will be able to inform a maintenance } \\
\text { regime? }\end{array}$ & $x$ & & & & & The monitoring system was only installed for research purposes. \\
\hline & $\begin{array}{l}\text { How likely is it that there will be a secure budget necessary for the intended period } \\
\text { of operation of the monitoring project? }\end{array}$ & & & & $x$ & & The research project was adequately funded. \\
\hline & Average & \multicolumn{5}{|c|}{$2 \cdot 1$} & Project may yield value to the asset owner/manager. \\
\hline
\end{tabular}

Table 5. Simulated pre-monitoring value assessment matrix

(Nine wells Bridge) 


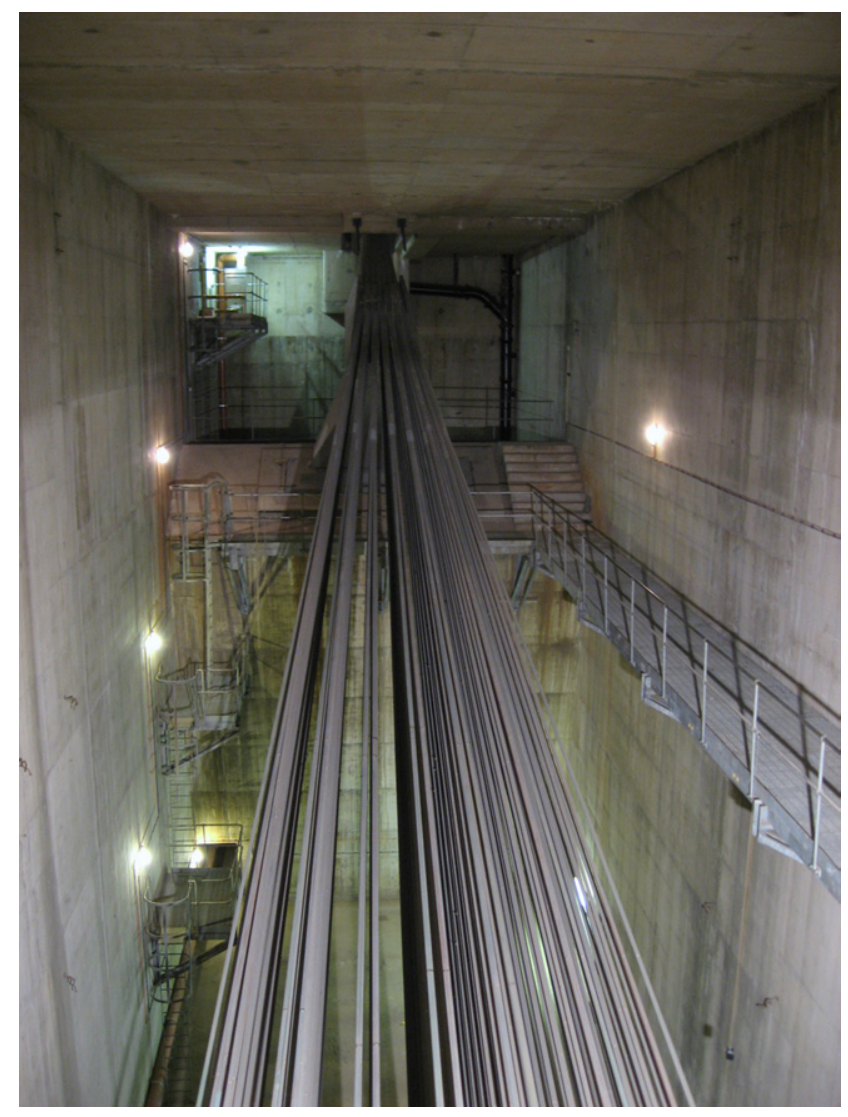

Figure 3. Humber Bridge: Hessle Anchorage (Photograph: Dr P. J. Bennett)

monitoring system has been in operation since July 2007 with minor upgrades. Although there have been outages, these were mainly attributable to battery exhaustion before a regular maintenance regime was put in place. With annual battery changes and maintenance, the system could remain operational for many further years. Table 6 shows the pre-monitoring assessment matrix filled out (albeit long after the project was initially installed) with a VR-index of 3.8 resulting. Based on the rating from Table 3, the project is 'likely to yield value to the asset owner/manager'. This good result is due to the fact that a welldefined relative humidity threshold was (is) able to be checked reasonably reliably.

\subsection{Ferriby Road Bridge (Hoult et al., 2010)}

The Ferriby Road Bridge (see Figure 4) is a three-span reinforced-concrete slab bridge on the northern approach to the Humber Bridge (some of the monitoring efforts are described in Hoult et al., 2010). During a visual inspection in 2002, several defects were noted. Firstly, cracks were spotted on the soffit of the slab which, although small in size, had the potential to grow and allow moisture ingress and possibly corrosion. Secondly, many of the bridge's elastomeric bearings

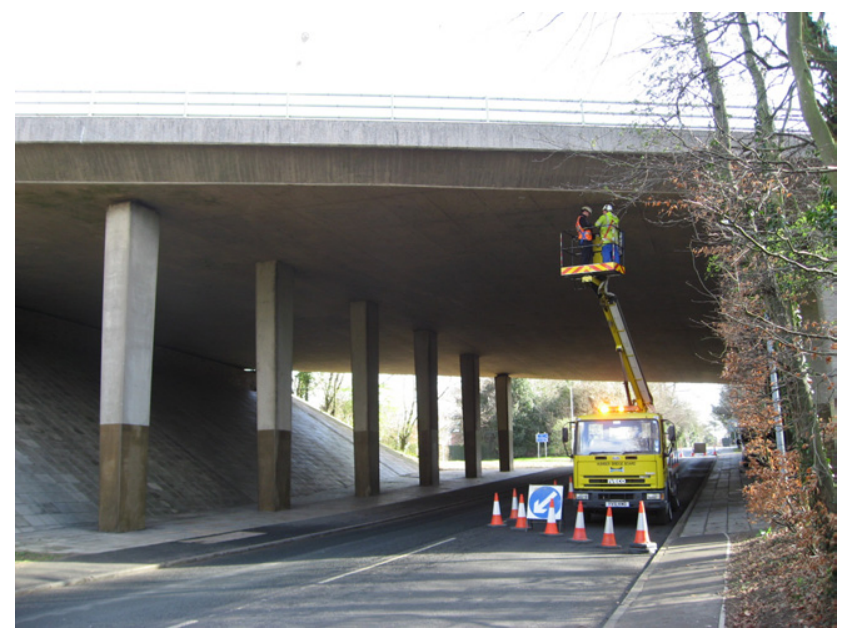

Figure 4. Ferriby Road Bridge (Photograph: Dr P. J. Bennett)

were slightly inclined, although it was not known whether these had been inclined since they were first installed or whether they had become inclined over time. These defects did not present an immediate cause for concern, but there was a potential benefit to the bridge manager in a monitoring system which would allow any changes or deterioration over time to be observed. A monitoring system was therefore installed to measure changes in the size of three of the soffit cracks and inclination of a number of the bearings. The crack width measurements have shown the crack openings remained constant over the three years during which the monitoring system was operational. Unfortunately in this installation the bearing inclinometers were less successful since the bearings were found to expand and contract due to temperature changes, regardless of whether the bridge deck itself was moving. It would therefore have been more useful to directly measure the displacement of the bridge deck with respect to the column, rather than attempting to infer this movement from the inclination of the bearings. This highlights the need for careful consideration during the design of any monitoring system. Table 7 shows the pre-monitoring assessment matrix filled out (albeit hypothetically but after an actual project was completed) with a VR-index of $2 \cdot 3$ resulting. Based on the rating from Table 3 , the project 'may yield value to the asset owner/manager'. This is a slightly better result than Walton Bridge, but clearly a less convincing result than the Humber anchorage deployment.

\subsection{Hammersmith flyover (Webb et al., 2014)}

The Hammersmith flyover is a $622 \mathrm{~m}$ long, 16-span, pre-stressed concrete bridge constructed in the early 1960s (further details are provided in Webb et al., 2014) (see Figure 5). Details of the original design are discussed in Rawlinson and Stott (1962) and Wroth (1962). Longitudinal movements owing to temperature variations are accommodated by roller bearings situated at the 


\begin{tabular}{|c|c|c|c|c|c|c|c|}
\hline & & 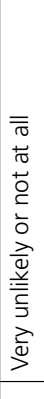 & 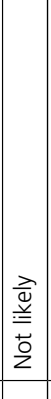 & 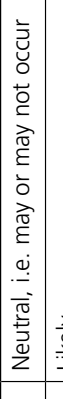 & 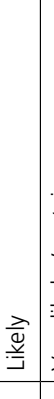 & 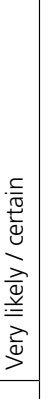 & \\
\hline & Question & 1 & 2 & 3 & 4 & 5 & Comments \\
\hline \multirow[t]{3}{*}{ SHM engineer } & $\begin{array}{l}\text { How likely is it that the required accuracy of the proposed measurements can } \\
\text { be ascertained? }\end{array}$ & & & & $x$ & & The datasheet for digital relative humidity $(\mathrm{RH})$ and temperature sensors was available. \\
\hline & $\begin{array}{l}\text { How likely is it that the specified system can be designed to be sufficiently } \\
\text { robust such that it can be maintained over the life of the monitoring } \\
\text { project? }\end{array}$ & & & & & $x$ & $\begin{array}{l}\text { The system was planned for a three-year deployment. The only maintenance required } \\
\text { for the sensors is to change the batteries. The data-logger has been replaced } \\
\text { since the original research project. The system has now been in place for } 9 \text { years } \\
\text { (as of 2016). }\end{array}$ \\
\hline & $\begin{array}{l}\text { How likely is it that the appropriate auditing will be conducted by a third } \\
\text { party to certify that the gathered data are reliable? } \\
\text { (For example, monthly reports that give details of calibrations undertaken } \\
\text { and 'sanity checking' of collected data.) }\end{array}$ & & & $\mathrm{x}$ & & & $\begin{array}{l}\text { Data were made available to the asset owner on a web-page that is still in operation } \\
\text { No active 'auditing' was undertaken, but the data can be readily checked. }\end{array}$ \\
\hline \multirow[t]{3}{*}{$\begin{array}{l}\text { Structural } \\
\text { engineer }\end{array}$} & $\begin{array}{l}\text { How likely is it that relevant values of appropriate threshold values will be } \\
\text { assigned in consultation with the asset owner so as to ensure that the } \\
\text { owner will act if these values are realised in the field? }\end{array}$ & & & & & $\mathrm{x}$ & A critical relative humidity $(\mathrm{RH})$ value of $60 \%$ was suggested by the asset owner. \\
\hline & $\begin{array}{l}\text { How likely is it that the critical monitoring locations on the structure can be } \\
\text { determined? }\end{array}$ & & & & $\mathrm{x}$ & & $\begin{array}{l}\text { Sensor locations were chosen on an ad-hoc basis - either near the strands, near the } \\
\text { wired sensors, or at locations suitable for relaying data from one sensor to another. } \\
\text { While this approach was successful it cannot be said if it was optimised or not. }\end{array}$ \\
\hline & $\begin{array}{l}\text { How likely is it that the data be used for validation (or falsification) of } \\
\text { structural models which may assist with the design of more efficient future } \\
\text { structures for the asset owner? }\end{array}$ & & $x$ & & & & $\begin{array}{l}\text { System just measures relative humidity of the anchorage chamber. While a basic } \\
\text { 'model' is needed to establish this threshold little structural performance/behaviour } \\
\text { can be monitored using this simple system. }\end{array}$ \\
\hline \multirow[t]{3}{*}{$\begin{array}{l}\text { Owner/Asset } \\
\text { manager }\end{array}$} & $\begin{array}{l}\text { How likely is it that the necessary actions (or decisions) will be taken if } \\
\text { threshold (trigger) values are exceeded/reached? }\end{array}$ & & & & $x$ & & $\begin{array}{l}\text { The obtained RH values may be used to check that the dehumidification system is } \\
\text { working (and, for example, if the hatch is left open). }\end{array}$ \\
\hline & $\begin{array}{l}\text { How likely is it that the data to be collected will be able to inform a } \\
\text { maintenance regime? }\end{array}$ & & $\mathrm{x}$ & & & & $\begin{array}{l}\text { A well-established trigger value was available and continued exceedance may lead to } \\
\text { increased maintenance or intervention but the causal link is not very clear. }\end{array}$ \\
\hline & $\begin{array}{l}\text { How likely is it that there will be a secure budget necessary for the intended } \\
\text { period of operation of the monitoring project? }\end{array}$ & & & & & $x$ & $\begin{array}{l}\text { After the initial 3-year research project ended, funds were made available by Humber } \\
\text { Bridge Board to continue the system. }\end{array}$ \\
\hline & Average & \multicolumn{5}{|c|}{3.8} & Project likely to yield value to the asset owner/manager. \\
\hline
\end{tabular}

Table 6. Simulated pre-monitoring value assessment matrix

(Humber Bridge Anchorage) 


\begin{tabular}{|c|c|c|c|c|c|c|c|}
\hline & & 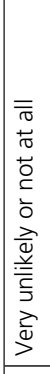 & 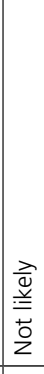 & 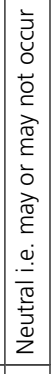 & 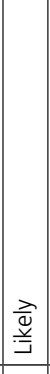 & 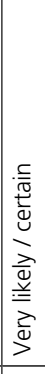 & \\
\hline & Question & 1 & 2 & 3 & 4 & 5 & Comments \\
\hline \multirow[t]{3}{*}{ SHM engineer } & $\begin{array}{l}\text { How likely is it that the required accuracy of the proposed measurements can be } \\
\text { ascertained? }\end{array}$ & & & $x$ & & & $\begin{array}{l}\text { 10-bit analogue to digital converter (ADC) for crack widths - datasheet available for } \\
\text { linear potentiometric displacement transducer (LPDT) LPDTs, } 16 \text { bit ADC for } \\
\text { inclinometer - inclinometer data available. No calibration done on integrated } \\
\text { sensors. }\end{array}$ \\
\hline & $\begin{array}{l}\text { How likely is it that the specified system can be designed to be sufficiently } \\
\text { robust such that it can be maintained over the life of the monitoring project? }\end{array}$ & & & $x$ & & & $\begin{array}{l}\text { This was a research system with some consideration made for packaging of sensors } \\
\text { and the need to change batteries for wireless sensors was identified. }\end{array}$ \\
\hline & $\begin{array}{l}\text { How likely is it that the appropriate auditing will be conducted by a third party } \\
\text { to certify that the gathered data are reliable? } \\
\text { (For example, monthly reports that give details of calibrations undertaken and } \\
\text { 'sanity checking' of collected data.) }\end{array}$ & & $x$ & & & & $\begin{array}{l}\text { Some data were measured (see Hoult et al., 2010), but little or no external auditing } \\
\text { was done in part due to the nature of the project (research). }\end{array}$ \\
\hline \multirow[t]{3}{*}{$\begin{array}{l}\text { Structural } \\
\text { engineer }\end{array}$} & $\begin{array}{l}\text { How likely is it that relevant values of appropriate threshold values will be } \\
\text { assigned in consultation with the asset owner so as to ensure that the owner } \\
\text { will act if these values are realised in the field? }\end{array}$ & $x$ & & & & & No sensible threshold available or decided upon. \\
\hline & $\begin{array}{l}\text { How likely is it that the critical monitoring locations on the structure can be } \\
\text { determined? }\end{array}$ & & $\mathrm{x}$ & & & & $\begin{array}{l}\text { Crack width sensor positions determined by looking for suitable cracks to monitor. } \\
\text { Only three cracks were monitored with no way of knowing if these locations } \\
\text { were critical. }\end{array}$ \\
\hline & $\begin{array}{l}\text { How likely is it that the data be used for validation (or falsification) of structural } \\
\text { models which may assist with the design of more efficient future structures } \\
\text { for the asset owner? }\end{array}$ & & & & $x$ & & The data may be used to study bearing performance. \\
\hline \multirow[t]{3}{*}{$\begin{array}{l}\text { Owner/Asset } \\
\text { manager }\end{array}$} & $\begin{array}{l}\text { How likely is it that the necessary actions (or decisions) will be taken if threshold } \\
\text { (trigger) values are exceeded/reached? }\end{array}$ & $x$ & & & & & No sensible thresholds available or decided upon. \\
\hline & $\begin{array}{l}\text { How likely is it that the data to be collected will be able to inform a } \\
\text { maintenance regime? }\end{array}$ & $x$ & & & & & $\begin{array}{l}\text { Research study and no direct link (or explicit) link to the bridge maintenance } \\
\text { regime. }\end{array}$ \\
\hline & $\begin{array}{l}\text { How likely is it that there will be a secure budget necessary for the intended } \\
\text { period of operation of the monitoring project? }\end{array}$ & & & & $x$ & & Budget was available for the research project stage but not long-term. \\
\hline & Average & \multicolumn{5}{|c|}{$2 \cdot 3$} & Project may yield value to the asset owner/manager. \\
\hline
\end{tabular}

Table 7. Simulated pre-monitoring value assessment matrix 


\begin{tabular}{|c|c|c|c|c|c|c|c|}
\hline & & 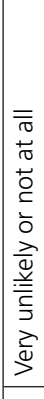 & $\begin{array}{l}\frac{\vec{Q}}{\overrightarrow{\underline{y}}} \\
\stackrel{\underline{\underline{0}}}{\mathrm{o}}\end{array}$ & 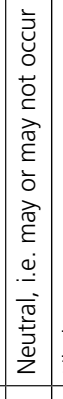 & . & 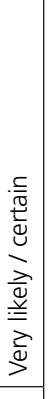 & \\
\hline & Question & 1 & 2 & 3 & 4 & 5 & Comments \\
\hline \multirow[t]{3}{*}{ SHM engineer } & $\begin{array}{l}\text { How likely is it that the required accuracy of the proposed measurements } \\
\text { can be ascertained? }\end{array}$ & & & $x$ & & & \\
\hline & $\begin{array}{l}\text { How likely is it that the specified system can be designed to be sufficiently } \\
\text { robust such that it can be maintained over the life of the monitoring } \\
\text { project? }\end{array}$ & & & $x$ & & & $\begin{array}{l}\text { Sensor design life was five years. } \\
\text { Flooding of the bearing pit did cause disruptions to the monitoring project. } \\
\text { Monitoring was intended to be very short term, to highlight areas of concern so } \\
\text { that further investigations could take place (varying between } 2,5 \text { and } 10 \text { years } \\
\text { in different locations). }\end{array}$ \\
\hline & $\begin{array}{l}\text { How likely is it that the appropriate auditing will be conducted by a third } \\
\text { party to certify that the gathered data are reliable? } \\
\text { (For example, monthly reports that give details of calibrations } \\
\text { undertaken and 'sanity checking' of collected data.) }\end{array}$ & & & $x$ & & & $\begin{array}{l}\text { Some ongoing scrutiny of the data was undertaken by the investigating } \\
\text { engineers. }\end{array}$ \\
\hline \multirow[t]{3}{*}{$\begin{array}{l}\text { Structural } \\
\text { engineer }\end{array}$} & $\begin{array}{l}\text { How likely is it that relevant values of appropriate threshold values will be } \\
\text { assigned in consultation with the asset owner so as to ensure that the } \\
\text { owner will act if these values are realised in the field? }\end{array}$ & & & $\mathrm{x}$ & & & $\begin{array}{l}\text { In establishing expected performance of the bearings some consultation with the } \\
\text { asset owner occurred. }\end{array}$ \\
\hline & $\begin{array}{l}\text { How likely is it that the critical monitoring locations on the structure can } \\
\text { be determined? }\end{array}$ & & & & & $x$ & $\begin{array}{l}\text { Monitoring points for the bearing relatively simple to establish and access to the } \\
\text { bearing pit possible. }\end{array}$ \\
\hline & $\begin{array}{l}\text { How likely is it that the data be used for validation (or falsification) of } \\
\text { structural models which may assist with the design of more efficient } \\
\text { future structures for the asset owner? }\end{array}$ & & & & $x$ & & $\begin{array}{l}\text { The data were compared with outputs from a basic finite-element model to } \\
\text { explore bearing behaviour. This could provide useful information for future } \\
\text { structural designs. }\end{array}$ \\
\hline \multirow[t]{3}{*}{$\begin{array}{l}\text { Owner/Asset } \\
\text { manager }\end{array}$} & $\begin{array}{l}\text { How likely is it that the necessary actions (or decisions) will be taken if } \\
\text { threshold (trigger) values are exceeded/reached? }\end{array}$ & & & $x$ & & & No firm initial plans - but the diagnosis did lead to some action. \\
\hline & $\begin{array}{l}\text { How likely is it that the data to be collected will be able to inform a } \\
\text { maintenance regime? }\end{array}$ & & & $x$ & & & $\begin{array}{l}\text { No clear link to ongoing maintenance, but the diagnosis did assist with some of } \\
\text { the upgrade work. }\end{array}$ \\
\hline & $\begin{array}{l}\text { How likely is it that there will be a secure budget necessary for the } \\
\text { intended period of operation of the monitoring project? }\end{array}$ & & & & & $x$ & Sufficient budget was available during the research and investigation phase. \\
\hline & Average & \multicolumn{5}{|c|}{3.6} & Project likely to yield value to the asset owner/manager. \\
\hline
\end{tabular}

Table 8. Simulated pre-monitoring value assessment matrix

(Hammersmith flyover roller bearing monitoring) 


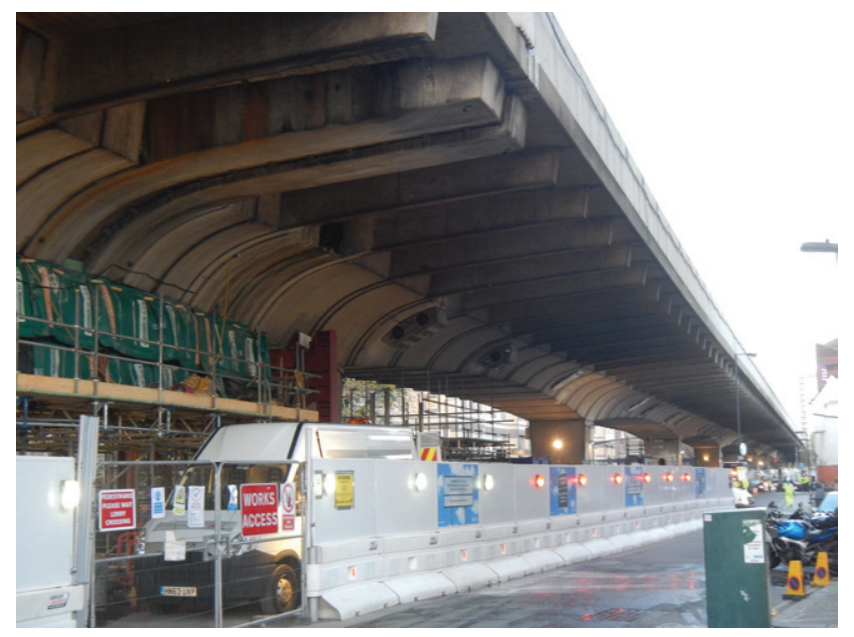

Figure 5. Hammersmith flyover (Photograph: Authors)

base of each pier. The bridge is fixed at each abutment with a single expansion joint located in a span towards the centre. Various monitoring techniques have been used on this bridge since late 2009, including an extensive wired system installed by a contractor and a wireless sensor network (WSN) installed by researchers working at the University of Cambridge. Further details of the analysis of some of the monitoring data have been presented in Webb et al. (2014).

The structure's owners were concerned that deterioration of the roller bearings at the base of each pier could result in restraint against longitudinal movement. If true this meant that expansion of the bridge deck due to temperature changes would induce extra bending moments in the piers and the bridge deck. These additional stresses could potentially exacerbate other problems caused by corrosion of the deck pre-stressing tendons.

Displacement gauges were installed to monitor the longitudinal movements of each bearing in addition to a number of temperature gauges distributed throughout the structure. Analysis of a structural model determined that restraint of any single bearing would have very little effect on the movements of the remaining bearings. This allowed damage detection to be implemented by analysing the correlation between temperature and movement for each pier. It became apparent that two of the bearings were moving to a far lesser extent than would have been expected. Subsequent visual inspections discovered that movement at these bearings was indeed being restricted, confirming the monitoring system's ability to detect a problem. It should be noted that a detailed analysis of the expected behaviour of the structure was a prerequisite to the success of this monitoring system; simply installing sensors and plotting the data obtained would have produced very little information of use. Table 8 shows the pre-monitoring assessment matrix filled out (albeit after the actual project was completed) with a VR-index of 3.6 resulting. Based on the rating from Table 3, the project is 'likely to yield value to the asset owner/manager'. This positive result is due to the fact that a good diagnosis of bearing performance was sought and achieved.

\section{Summary remarks}

This paper proposes a set of questions that allow for an assessment of the potential value of bridge monitoring systems. The developed value assessment methodology has been trialled hypothetically on five bridge monitoring studies with which the authors are familiar. The need for the SHM engineer, structural engineer and owner all to contribute to the pursuit of potential value is central to the methodology.

For the five case studies reviewed in this paper the computed average value ratings are seen to range from 1.9 to $3 \cdot 8$. The relatively low scores across these deployments are a reminder that it remains difficult to get value from bridge monitoring. In spite of this, useful information can sometimes be obtained and it is suggested that this is more likely to occur if due consideration is given to the needs of the asset owner, as discussed in this paper.

\section{Acknowledgements}

This work was supported by Engineering \& Physical Sciences Research Council (EPSRC) grant no: EP/I019308/1 and EP/K000314/1: Innovation Knowledge Centre for Smart Infrastructure and Construction. The authors note that this paper relies on no underlying datasets.

\section{REFERENCES}

Andersen JE and Vesterinen A (2006) Structural Health Monitoring Systems. COWI Futuretec, Kongens Lyngby, Denmark. See http://www.shms.dk/COWI_ISBN-87-9104404-9.pdf (accessed 25/11/2015).

Bloomstine ML (2011) Main cable corrosion protection by dehumidification-experience, optimization and new development. In Modern Techniques in Bridge Engineering: Proceedings of 6th New York City Bridge Conference, 25-26 July 2011 (Mahmoud KM (ed.)). CRC Press, Taylor \& Francis Group, Boca Raton, FL, USA, pp. 39-54.

BTS (British Tunnelling Society) (2011) Monitoring Underground Construction: A Best Practice Guide. ICE Publishing, London, UK.

Catbas FN, Kijewski-Correa T and Aktan AE (eds) (2013) Structural Identification of Constructed Systems: Approaches, Methods, and Technologies for Effective Practice of St-Id. American Society of Civil Engineers, Reston, Virginia, USA.

Cole G (2008) The role of assessments in highway bridge management. Proceedings of the Institution of Civil Engineers - Bridge Engineering 161(3): 133-139, http://dx.doi.org/10.1680/bren.2008.161.3.133.

Feltrin G (ed.) (2007) Monitoring Guidelines for Railway Bridges. Document Number: Deliverable D5.2. See 
http://www.sustainablebridges.net/main.php/SB5.2_Guideline_ MON.pdf?fileitem=14043925 (accessed 25/11/2015).

Gastineau A, Johnson T and Schultz A (2009) Bridge Health

Monitoring and Inspections Systems - A Survey of Methods.

Department of Transportation, St. Paul, Minnesota, USA,

Report No. MN/RC 2009-29. See http://www.lrrb.org/pdf/ 200929.pdf (accessed 25/11/2015).

Hoult NA, Fidler PRA, Wassell IJ, Hill PG and Middleton CR (2008) Wireless structural health monitoring at the Humber Bridge UK. Proceedings of the Institution of Civil Engineers - Bridge Engineering 161(4): 189-195, http://dx.doi.org/10.1680/bren.2008.161.4.189.

Hoult NA, Bennett PJ, Fidler PRA, Middleton CR and Soga K

(2009) Distributed fibre optic strain measurements for pervasive monitoring of civil infrastructure. Proceedings 4th International Conference on Structural Health Monitoring of Intelligent Infrastructure (SHMII-4), Zurich, Switzerland, International Society for Structural Health Monitoring of Intelligent Infrastructure, Winnipeg, MB, Canada.

Hoult NA, Fidler PRA, Hill PG and Middleton CR (2010)

Long-term wireless structural health monitoring of the Ferriby Road Bridge. Journal of Bridge Engineering (American Society of Civil Engineers) 15(2): 153-159, http://dx.doi.org/10.1061/(ASCE)BE.1943-5592.0000049.

Ko JM and Ni YQ (2005) Technology developments in structural health monitoring large-scale bridges. Engineering Structures 27(12): 1715-1725, http://dx.doi.org/10.1016/ j.engstruct.2005.02.021.

Koo KY, Brownjohn JMW, List DI and Cole R (2013) Structural health monitoring of the Tamar suspension bridge. Structural Control and Health Monitoring 20(4): 609-625, http://dx.doi.org/10.1002/stc.1481.

Kurashima T, Horiguchi T, Izumita $\mathrm{H}$, Furukawa $\mathrm{S}$ and Koyamada Y (1993) Brillouin optical-fiber time domain reflectometry. IEICE Transactions on Communications E76-B(4): 382-390.

Kurata M, Kim J, Lynch JP et al. (2013) Internet-enabled wireless structural monitoring systems: development and permanent deployment at the new Carquinez suspension bridge. Journal of Structural Engineering (American Society of Civil Engineers) 139(10): 1688-1702, http:// dx.doi.org/10.1061/(ASCE)ST.1943-541X.0000609.

Maser KR (1988) Sensors for infrastructure assessment. Journal of Performance of Constructed Facilities (American Society of Civil Engineers) 2(4): 226-241, http://dx.doi.org/ 10.1061/(ASCE)0887-3828(1988)2:4(226).

Middleton C, Vardanega P, Webb G and Fidler P (2014) Smart infrastructure - are we delivering on the promise? Keynote Paper: 6th Australian Small Bridges Conference, Sydney, Australia, 27-28 May 2014, http://dx.doi.org/10.13140/RG. 2.1.1463.5288.

Poulos HG (2004) An approach for assessing geotechnical reduction factors for pile design. In Proceedings of the 9th Australia New Zealand Conference on Geomechanics Auckland, New Zealand. New Zealand Geotechnical Society and the Australian Geomechanics Society, Auckland, vol. 1, pp. 109-115.

Rawlinson J and Stott PF (1962) The Hammersmith flyover (includes plates). ICE Proceedings 23(4): 565-600, http:// dx.doi.org/10.1680/iicep.1962.10813.

Schwamb T (2010) Optical Strain Sensing for Piled Foundations at Ninewell's Bridge. MRes thesis, University College London University of Cambridge, London-Cambridge, UK.

Vaghefi K, Oats RC, Harris DK et al. (2012) Evaluation of commercially available remote sensors for highway bridge condition assessment. Journal of Bridge Engineering (American Society of Civil Engineers) 17(6): 886-895, http://dx.doi.org/10.1061/(ASCE)BE.1943-5592.0000303.

Webb GT (2014) Structural Health Monitoring of Bridges. $\mathrm{PhD}$ thesis, University of Cambridge, Cambridge, UK.

Webb GT, Vardanega PJ, Fidler PRA and Middleton CR (2014) Analysis of structural health monitoring data from Hammersmith flyover. Journal of Bridge Engineering (American Society of Civil Engineers) 19(6): 05014003, http://dx.doi.org/10.1061/(ASCE)BE.1943-5592.0000587.

Webb GT, Vardanega PJ and Middleton CR (2015) Categories of SHM deployments: technologies and capabilities. Journal of Bridge Engineering (American Society of Civil Engineers) 20(11): 04014118, http://dx.doi.org/10.1061/ (ASCE)BE.1943-5592.0000735.

Wong KY (2004) Instrumentation and health monitoring of cable-supported bridge. Structural Control and Health Monitoring 11(2): 91-124, http://dx.doi.org/10.1002/stc.33.

Wroth CP (1962) The Hammersmith flyover - site measurements of prestressing losses and temperature movement. ICE Proceedings 23(4): 601-624, http://dx.doi. org/10.1680/iicep.1962.10814.

Yanev B (2007) Bridge Management. John Wiley \& Sons, Hoboken, NJ, USA.

\section{WHAT DO YOU THINK?}

To discuss this paper, please email up to 500 words to the editor at journals@ice.org.uk. Your contribution will be forwarded to the author(s) for a reply and, if considered appropriate by the editorial panel, will be published as discussion in a future issue of the journal.

Proceedings journals rely entirely on contributions sent in by civil engineering professionals, academics and students. Papers should be 2000-5000 words long (briefing papers should be 1000-2000 words long), with adequate illustrations and references. You can submit your paper online via www.icevirtuallibrary.com/content/journals, where you will also find detailed author guidelines. 